\title{
Full Blockade of Intestinal P-glycoprotein and Extensive Inhibition of Blood-brain Barrier P-glycoprotein by Oral Treatment of Mice with PSC833
}

\author{
Ulrich Mayer, ${ }^{\star}$ Els Wagenaar, ${ }^{\star \ddagger}$ Birgit Dorobek,, Jos H. Beijnen, ${ }^{\rrbracket}$ Piet Borst, ${ }^{\star}$ and Alfred H. Schinkel ${ }^{\star \ddagger}$ \\ $*$ Division of Molecular Biology and ${ }^{\ddagger}$ Division of Experimental Therapy, The Netherlands Cancer Institute, Plesmanlaan 121,1066 CX \\ Amsterdam, The Netherlands; ${ }^{\S}$ European Cancer Centre, 1066 AE Amsterdam, The Netherlands; "Novartis Pharma Inc., CH-4002 Basel, \\ Switzerland; and ${ }^{\mathbb{I}}$ Department of Pharmacy, Slotervaart Hospital, 1066 AE Amsterdam, The Netherlands
}

\begin{abstract}
Mice lacking mdr1-type P-glycoproteins (mdr1a/1b [-/-] mice) display large changes in the pharmacokinetics of digoxin and other drugs. Using the kinetics of digoxin in mdrla/1b ( $-I-)$ mice as a model representing a complete block of P-glycoprotein activity, we investigated the activity and specificity of the reversal agent SDZ PSC833 in inhibiting mdr1-type P-glycoproteins in vivo. Oral PSC833 was coadministered with intravenous $\left[{ }^{3} \mathrm{H}\right]$ digoxin to wild-type and mdr1a/1b $(-/-)$ mice. The direct excretion of $\left[{ }^{3} \mathrm{H}\right] \mathrm{di}-$ goxin mediated by P-glycoprotein in the intestinal mucosa of wild-type mice was abolished by administration of PSC833. Hepatobiliary excretion of $\left[{ }^{3} \mathrm{H}\right]$ digoxin was markedly decreased in both wild-type and mdrla/1b (-l-) mice by PSC833, the latter effect indicating that in vivo, PSC833 inhibits not only mdr1-type P-glycoproteins, but also other drug transporters. Upon coadministration of PSC833, brain levels of $\left[{ }^{3} \mathrm{H}\right]$ digoxin in wild-type mice showed a large increase, approaching (but not equaling) the levels found in brains of PSC833-treated mdr1a/1b $(-l-)$ mice. Thus, orally administered PSC833 can inhibit blood-brain barrier P-glycoprotein extensively, and intestinal P-glycoprotein completely. These profound pharmacokinetic effects of PSC833 treatment imply potential risks, but also promising pharmacological applications of the use of effective reversal agents. (J. Clin. Invest. 1997. 100:2430-2436.) Key words: digoxin • reversal agent $\bullet$ excretion $\bullet$ pharmacokinetics $\bullet$ drug disposition
\end{abstract}

\section{Introduction}

The mdr1-type or drug-transporting P-glycoproteins (P-gps) ${ }^{1}$ were discovered by their ability to confer multidrug resistance (MDR) to mammalian tumor cells. These large plasma membrane proteins can actively transport a wide range of structurally diverse cytotoxic drugs out of the cell, rendering it resis-

Address correspondence to Dr. Alfred H. Schinkel, Division of Experimental Therapy, The Netherlands Cancer Institute, Plesmanlaan 121, 1066 CX Amsterdam, The Netherlands. Phone: +31-20-5122046; FAX: +31-20-5122050; E-mail: alfred@nki.nl

Received for publication 1 July 1997 and accepted in revised form 17 Sept 1997.

1. Abbreviations used in this paper: CNS, central nervous system; MDR, multidrug resistance; P-gp, P-glycoprotein.

J. Clin. Invest.

(C) The American Society for Clinical Investigation, Inc. 0021-9738/97/11/2430/07 \$2.00

Volume 100, Number 10, November 1997, 2430-2436

http://www.jci.org tant to the toxic action of the drugs. Compounds transported by P-gp include many clinically important drugs such as anticancer agents (e.g., Vinca alkaloids, anthracyclines, epipodophyllotoxins, taxanes), but also immunosuppressive drugs (cyclosporin A, FK506), anthelmintic agents (ivermectin), steroids (aldosterone, hydrocortisone, dexamethasone) and cardiac drugs (digoxin), to name just a few (1-5).

The potential involvement of MDR1 P-gp in the MDR frequently observed during chemotherapy of human clinical tumors has led to efforts to inhibit P-gp-mediated drug transport with pharmacological inhibitors of P-gp. These compounds, called reversal agents or P-gp modulators, appear to inhibit P-gp activity mostly by competing with the binding and/or transport of a transported drug. Reversal agents are as widely divergent in structure as the known drug substrates for P-gp, and many are themselves also transported $(6,7)$. Initial efforts to treat patients with MDR tumors in a combination treatment with a reversal agent met at best with very limited success, but the early reversal agents were relatively inefficient, and their dosage was severely limited by inherent toxicity to the patient (810). Recently, however, more effective and less toxic reversal agents have become available (11-15). PSC833, a nonimmunosuppressive cyclosporin A analogue is one of the most effective, and clinical trials with this compound are currently ongoing (see reference 10).

It can be expected that administration of effective reversal agents will also inhibit the function of the MDR1 P-gp present in a range of normal tissues, and the physiological and pharmacological consequences of this treatment cannot be predicted in the absence of clear insight in the normal function of MDR1 P-gp. To establish the physiological and pharmacological function of the mdr1-type P-gps, we have generated mice with a genetic deficiency in both the mouse $m d r 1 a$ and $m d r 1 b$ genes $(16,17)$. Unlike man, mice have two highly homologous mdr1type genes encoding drug-transporting P-gps, but the tissue distribution and subcellular localization of these P-gps strongly suggest that they fulfill essentially the same role(s) as the single human MDR1 P-gp. Typically, the mouse mdr1a P-gp is abundant in the apical membrane of epithelial cells throughout the intestine, in biliary canalicular membranes of hepatocytes, and in the luminal membrane of endothelial cells in blood capillaries in the brain, i.e., at the blood-brain barrier. Mouse mdr1b P-gp is especially prominent in adrenal gland plasma membranes and endometrium of pregnant uterus, and it further occurs in kidney, liver, and the hematopoietic compartment (16-20). Human MDR1 P-gp has been found in intestinal epithelial cells, biliary canalicular membranes, the luminal surface of proximal tubules in the kidney, in the blood-brain and blood-testis barriers, the adrenal gland, and in the hematological compartment (21-24).

Mice deficient for the mdr1a and mdr1b P-gps (mdr1a/1b $(-/-)$ mice) are viable and fertile, and so far we have not found any physiological abnormalities in these mice under lab- 
oratory conditions (17). We have, however, demonstrated profound changes in the pharmacological handling of a range of drugs by these mice and by mdrla (-/-) mice, including highly increased brain penetration, and drastically altered elimination, excretion, and oral bioavailability of drugs, sometimes resulting in strikingly altered toxicity $(16,17,25-29)$.

In this study we have used the mdr1a/1b (-/-) mice as a reference model to establish how effective and how specific the P-gp-inhibiting action of the reversal agent PSC833 is in vivo. We used $\left[{ }^{3} \mathrm{H}\right]$ digoxin as a model $\mathrm{P}$-gp substrate drug in view of its comparatively low toxicity in rodents (30), and its highly P-gp dependent pharmacokinetics in mice $(17,25,27)$.

\section{Methods}

Drugs. $\left[{ }^{3} \mathrm{H}(\mathrm{G})\right]$ digoxin $(16.0 \mathrm{Ci} / \mathrm{mmol})$ was obtained from DuPontNEN (Boston, MA). SDZ PSC833 was a kind gift from Sandoz Pharma Nederland B.V. (Uden, The Netherlands). Hypnorm ${ }^{\circledR}$ was from Janssen Pharmaceuticals B.V. (Tilburg, The Netherlands). Dormicum $^{\circledR}$ was from Roche Nederland B.V. (Mijdrecht, The Netherlands). Digoxin was from Sigma Chemical Co. (St Louis, MO).

Drug distribution and excretion experiments. The experiments were carried out in female mice of a mixed genetic background (on average $50 \%$ FVB, $50 \% 129 / \mathrm{Ola}$ ). The mice were between 10-14 wk of age. All animal experiments were carried out according to institutional guidelines, in compliance with Dutch national law.

A stock solution of $50 \mathrm{mg} / \mathrm{ml} \mathrm{PSC} 833$ was prepared in ethanol (33\% vol/vol) and cremophor EL ( $65 \% \mathrm{vol} / \mathrm{vol})$, and was further diluted in $5 \%(\mathrm{wt} / \mathrm{vol})$ glucose to a final concentration of $5 \mathrm{mg} / \mathrm{ml}$. For control experiments the same solution was prepared without adding PSC833. To achieve a dosage of $50 \mathrm{mg} / \mathrm{kg}$ mouse body weight, PSC833 or the control solution were administered at $10 \mu \mathrm{l} / \mathrm{g}$ body wt by transoral intragastric injection $2 \mathrm{~h}$ before digoxin application, using a blunt-ended needle. The unlabeled digoxin stock $(2 \mathrm{mg} / \mathrm{ml}$ in water plus $20 \%$ [vol $/ \mathrm{vol}] 1.2$ - propanediol, $40 \%$ [vol $/ \mathrm{vol}]$ ethanol, and $2 \%$ [wt/vol] glucose) was diluted in $5 \%$ glucose to $0.01 \mathrm{mg} / \mathrm{ml}$ for intravenous administration $(0.05 \mathrm{mg} / \mathrm{kg})$. $\left[{ }^{3} \mathrm{H}\right]$ digoxin $(1 \mu \mathrm{Ci} / 30 \mathrm{~g}$ body weight) was added shortly before the experiment.

For drug distribution experiments, mice were killed 4 or $24 \mathrm{~h}$ after digoxin administration $(n=4)$. Plasma, tissues and intestinal contents were collected. Urine and excreted feces were collected using metabolic cages. Bile cannulation experiments were carried out as described previously (27). In brief, mice were anaesthetized using a combination of Hypnorm (1 part), Dormicum (1 part), and 5\% glucose ( 2 parts). $4 \mu \mathrm{l} / \mathrm{g}$ body wt of the anaesthetic solution was administered intraperitoneally to mice, which had received PSC833 $2 \mathrm{~h}$ before the cannulation experiment. In control mice $6 \mu \mathrm{l} / \mathrm{g}$ body wt was injected intraperitoneally After opening the abdominal cavity, the common bile duct was ligated and a catheter was inserted into the gallbladder. $\left[{ }^{3} \mathrm{H}\right]$ digoxin was administered intravenously and bile was collected for $90 \mathrm{~min}$. At the end of that period mice were killed, and organs, intestinal contents, and plasma were collected.

Acute side effects of PSC 833 at a dose of $50 \mathrm{mg} / \mathrm{kg}$ were not observed. In bile cannulation experiments, however, both wild-type and $m d r 1 a / 1 b(-/-)$ mice appeared significantly more sensitive to the anaesthesia (midazolam-fluanisone-fentanyl) when pretreated with PSC833. Hence, a $40 \%$ reduction of the dose of the anaesthetics in comparison to control mice was necessary. A small-scale toxicity experiment, giving the anaesthetic components as a single drug, showed that this was due to an increased sensitivity to fentanyl after PSC833 administration (data not shown). A very similar effect was previously demonstrated with cyclosporin A in combination with fentanyl (31), and it seems likely that a comparable mechanism is involved.

For scintillation counting, tissues and intestinal contents were homogenized in $4 \%$ (wt/vol) BSA, before a fixed amount of each homogenate, urine, bile or plasma were transferred to Ultima Gold Scintilla- tion Fluid (100 $\mu \mathrm{l}$ for plasma, $25 \mu \mathrm{l}$ for bile and urine, $200 \mu \mathrm{l}$ for homogenates).

Measurement of bile acids and phosphatidylcholine in bile samples. Female wild-type mice (50\% FVB, 50\% 129/Ola, between 1014 wk of age) were used. Mice received oral PSC833 $(50 \mathrm{mg} / \mathrm{kg})$ or cremophor-containing vehicle alone $(n=8) .2 \mathrm{~h}$ later the gallbladder of the anaesthetized mice was cannulated, and bile was collected over 90 min. Determination of bile acids in bile was performed using 3-hydroxysteroid dehydrogenase (32). Phosphatidylcholine excretion into bile was determined by using the choline oxidase method (33).

For determination of PSC833 levels in brain and plasma, $100 \mu \mathrm{l}$ of the sample was extracted with $1000 \mu \mathrm{l}$ of methanol by vigorous vortexing for $1 \mathrm{~min}$. After centrifugation $\left(4,000 \mathrm{~g}, 5 \mathrm{~min}, 4^{\circ} \mathrm{C}\right)$ the supernatant was decanted and evaporated to dryness under a vacuum at $50^{\circ} \mathrm{C}$. Each extract was then reconstituted in an appropriate volume of phosphate buffer (containing human plasma, monoclonal antibody against cyclosporin A, dihydro-[G- $\left.{ }^{3} \mathrm{H}\right] \mathrm{SDZ}$ PSC833 tracer, and charcoal), and PSC833 concentration was determined by specific radioimmunoassay according to an internal standard operating procedure.

Statistical analysis. Student's unpaired $t$ test was used to test the statistical significance of a difference between two sets of data. $P<$ 0.05 was considered statistically significant.

\section{Results}

To study the in vivo efficacy and specificity of PSC833 in inhibiting $\mathrm{P}-\mathrm{gp}-\mathrm{mediated}$ transport of $\left[{ }^{3} \mathrm{H}\right]$ digoxin in various organs, the reversal agent was administered orally at a dose of 50 $\mathrm{mg} / \mathrm{kg} 2 \mathrm{~h}$ before intravenous administration of $\left[{ }^{3} \mathrm{H}\right]$ digoxin (at $0.05 \mathrm{mg} / \mathrm{kg}$ ) to wild-type and mdr1a/1b (-/-) mice. As a control, groups of both strains received the vehicle cremophor alone instead of PSC833. Unless indicated otherwise, this treatment schedule was used in all experiments. Acute toxic side effects of PSC 833 at a dose of $50 \mathrm{mg} / \mathrm{kg}$ were not observed (for further details see Methods). We focused on the effects of the reversal agent on the excretion pattern and the brain distribution of $\left[{ }^{3} \mathrm{H}\right]$ digoxin, as in previous experiments these parameters were most profoundly influenced by the absence of P-gp (from intestinal mucosa and brain endothelial cells, respectively) in mdrla $(-/-)$ and $m d r 1 a / 1 b(-/-)$ mice $(17,27)$.

Fig. 1 shows the fecal and urinary excretion of $\left[{ }^{3} \mathrm{H}\right]$ digoxin over $24 \mathrm{~h}$ in wild-type and $m d r 1 a / 1 b(-/-)$ mice with or without PSC833. The predominantly fecal excretion of $\left[{ }^{3} \mathrm{H}\right]$ digoxin occurring in wild-type mice was clearly shifted towards predominantly urinary excretion upon PSC833 treatment. In fact, the excretion pattern became very similar to that in $m d r 1 a / 1 b$ $(-/-)$ mice without PSC833, which likewise showed a predominantly urinary excretion (Fig. 1). PSC833 treatment of $m d r 1 a / 1 b(-/-)$ mice increased the urinary excretion component even further $(P<0.02)$. Similar effects of PSC833 treatment were observed when digoxin (at $0.05 \mathrm{mg} / \mathrm{kg}$ ) was administered orally to wild-type or $m d r 1 a / 1 b(-/-)$ mice (data not shown).

We have previously shown that the main cause for the reduced fecal excretion of digoxin and paclitaxel (Taxol ${ }^{\circledR}$ ) in $\mathrm{P}$-gp-deficient mice is the strongly reduced excretion of these drugs directly across the intestinal mucosa $(17,27,29)$. Fig. $2 A$ shows that in wild-type mice with a ligated common bile duct and a cannulated gallbladder (thus allowing separate measurement of hepatobiliary and intestinal excretion), pretreatment with oral PSC833 indeed reduced the direct intestinal excretion of $\left[{ }^{3} \mathrm{H}\right]$ digoxin from $16 \%$ of the administered dose (over $90 \mathrm{~min}$ ) to only $1 \%$. In contrast, the very low level of $\left[{ }^{3} \mathrm{H}\right]$ digoxin excretion occurring in $m d r 1 a / 1 b(-/-)$ intestine 


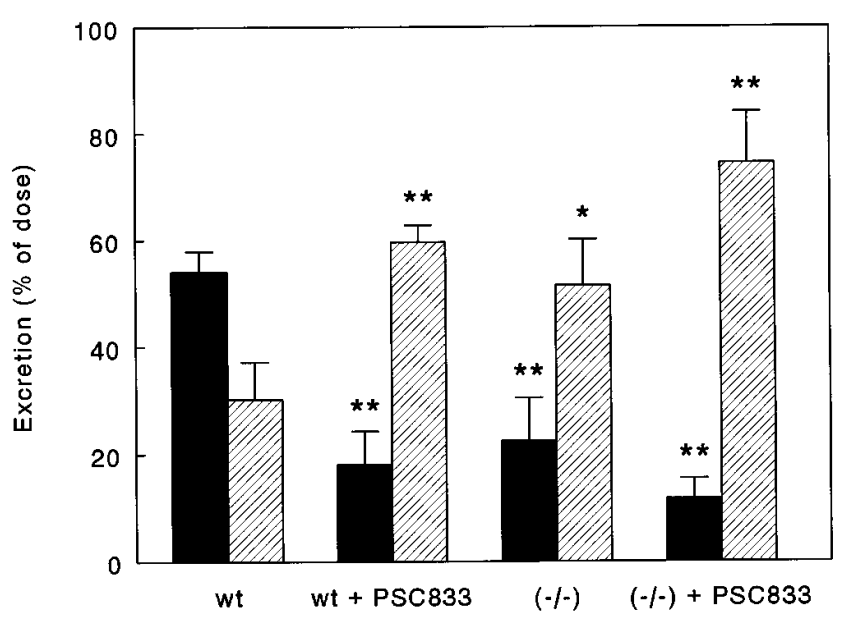

Figure 1. Effect of PSC833 on fecal and urinary $\left[{ }^{3} \mathrm{H}\right]$ digoxin excretion. Fecal (black bars) and urinary (hatched bars) excretion of $\left[{ }^{3} \mathrm{H}\right]$ digoxin was measured in wild-type $(w t)$ and $m d r l a / 1 b(-/-)$ mice pretreated with PSC 833 or vehicle alone over $24 \mathrm{~h}$ after an intravenous bolus of $\left[{ }^{3} \mathrm{H}\right]$ digoxin $(0.05 \mathrm{mg} / \mathrm{kg}$ ). PSC833 (or vehicle) was administered orally at $50 \mathrm{mg} / \mathrm{kg} 2 \mathrm{~h}$ before the digoxin injection. Levels are expressed as a percentage of the administered dose (mean $\pm \mathrm{SD}, n=4)$. Significance of differences with values for vehicle-treated wild-type mice is indicated: $* P<0.01 ; * * P<0.001$.

was not significantly altered by PSC833 treatment (Fig. $2 A$ ). It thus appears that oral PSC833 can completely inhibit excretory $\mathrm{P}$-gp-mediated $\left[{ }^{3} \mathrm{H}\right]$ digoxin transport in the intestine of wildtype mice.

In previous gallbladder cannulation experiments we found that the excretion of $\left[{ }^{3} \mathrm{H}\right]$ digoxin into bile over $90 \mathrm{~min}$ was only moderately, albeit significantly, decreased in $m d r 1 a / 1 b(-/-)$ mice when compared with wild-type mice (17). Therefore, transporters other than the mdr1-type P-gps must also be involved in the biliary excretion of digoxin. Interestingly, when PSC833 was coadministered with $\left[{ }^{3} \mathrm{H}\right]$ digoxin, biliary excretion of the drug substantially dropped in both wild-type and mdr1a/
$1 b(-/-)$ mice from $14-21 \%$ to $<5 \%$ of the initially given dose (Fig. 2 B). In each case, an immunoassay demonstrated that at least $80 \%$ of the radioactivity recovered in bile represented digoxin or closely related, pharmacologically active metabolites (not shown). The results indicate that, in addition to the mdr1-type P-gps, PSC833 must also inhibit another hepatic transporter (or transporters) of $\left[{ }^{3} \mathrm{H}\right]$ digoxin. The remaining level of biliary $\left[{ }^{3} \mathrm{H}\right]$ digoxin excretion $(3.5-4.1 \%$ of administered dose) could result either from incomplete inhibition of these other transporters by PSC833, or from the presence of a PSC833-resistant digoxin transporter. In this cannulation experiment, plasma levels of $\left[{ }^{3} \mathrm{H}\right]$ digoxin in $m d r l a / 1 b(-/-)$ mice and in PSC833-treated mice were about twofold higher after 90 min when compared with vehicle-treated wild-type mice, in accordance with the diminished $\left[{ }^{3} \mathrm{H}\right]$ digoxin excretion capacity of these mice (Table I).

In rats, high-dose oral cyclosporin A (CsA) substantially decreases bile salt and phospholipid output into bile as well as the bile flow (F. Kuipers, personal communication; 34). As PSC833 is a CsA analogue, we also tested these parameters in the PSC833-treated mice. The parameters were not altered in untreated $m d r l a / 1 b(-/-)$ mice (17), indicating that direct involvement of the mdr1-type P-gps in the measured processes is unlikely. We determined bile salt and phospholipid excretion as well as bile flow in wild-type mice pretreated with PSC833 or with cremophor alone. As shown in Table II, the PSC833 treatment did not significantly affect any of the measured parameters $(P \geq 0.10)$, indicating that oral PSC833 treatment at this dosage does not affect bile flow, bile salt transport, or phospholipid excretion mediated by the mdr2 P-gp. Thus, it is unlikely that alterations in bile composition or bile flow could explain the observed decrease in hepatobiliary $\left[{ }^{3} \mathrm{H}\right]$ digoxin excretion caused by PSC833.

To investigate to what extent orally administered PSC833 can also block P-gp activity in the blood-brain barrier, we determined the brain distribution of $\left[{ }^{3} \mathrm{H}\right]$ digoxin 4 and $24 \mathrm{~h}$ after intravenous administration to wild-type or mdr1a/1b (-/-) mice with or without pretreatment with PSC833. Table III shows the plasma and brain concentrations obtained in this experiment. Two factors complicate the interpretation of these
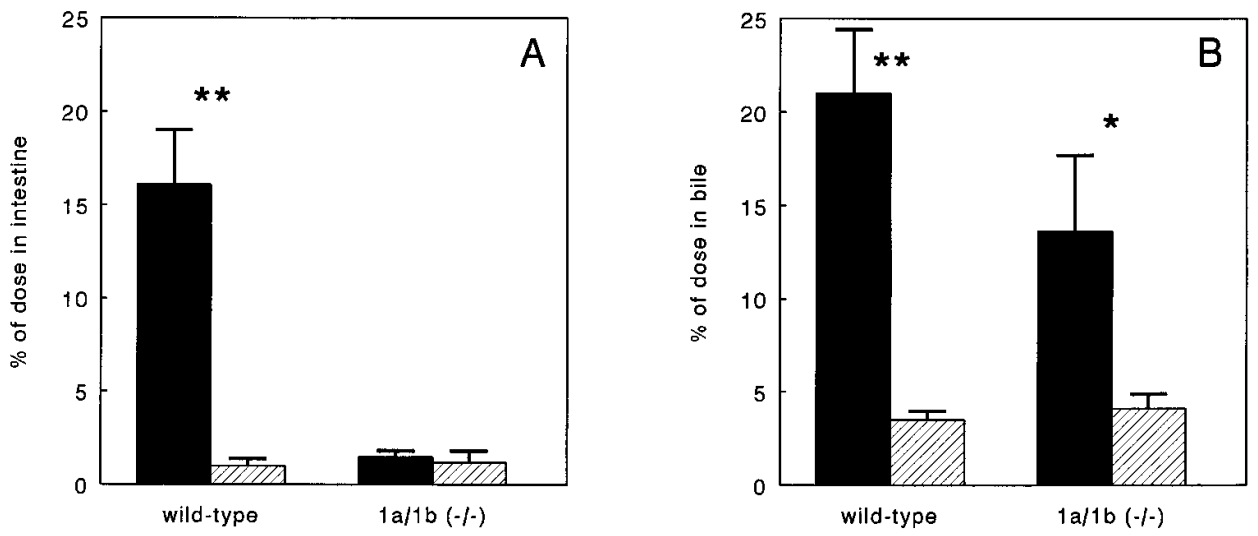

Figure 2. Effect of PSC833 on intestinal and biliary $\left[{ }^{3} \mathrm{H}\right]$ digoxin excretion in wild-type and $m d r 1 a / 1 b$ $(-/-)$ mice. $(A) \mathrm{P}$-gp mediated intestinal excretion of $\left[{ }^{3} \mathrm{H}\right]$ digoxin in anaesthetized mice with a ligated common bile duct and a cannulated gallbladder. $90 \mathrm{~min}$ after intravenous injection of $\left[{ }^{3} \mathrm{H}\right]$ digoxin $(0.05$ $\mathrm{mg} / \mathrm{kg}$ ), intestinal contents were collected. Black bars indicate the intestinal excretion of vehicle-treated mice; hatched bars show the excretion in mice pretreated with oral PSC833 $(50 \mathrm{mg} / \mathrm{kg})$. Levels are expressed as percentage of the administered dose (means $\pm \mathrm{SD}, n=4)$. ${ }^{*} P<0.001$ for each pair of columns. $(B)$ Biliary excretion of $\left[{ }^{3} \mathrm{H}\right]$ digoxin. In the mice described in $A$, bile was collected over $90 \mathrm{~min}$ after the intravenous bolus injection of $\left[{ }^{3} \mathrm{H}\right]$ digoxin $(0.05 \mathrm{mg} / \mathrm{kg})$. Black bars indicate biliary excretion in vehicle-treated mice, hatched bars show excretion in mice pretreated with oral PSC $833(50 \mathrm{mg} / \mathrm{kg})$. Levels are expressed as percentage of the administered dose (means $\pm \mathrm{SD}, n=4) . * P<0.005 ; * P<0.001$ for each pair of columns. 
Table I. Plasma and Brain Levels of Radioactivity $90 \mathrm{~min}$ After Intravenous Administration of $\left[{ }^{3} H\right]$ digoxin to Mice with a Cannulated Gallbladder

\begin{tabular}{lccc}
\hline & Plasma & Brain & Ratio brain/plasma \\
\hline & $n g / m l$ & $n g / g$ & \\
Wild-type & $21.2 \pm 3.8$ & $1.1 \pm 0.4$ & $0.052 \pm 0.021$ \\
Wild-type + PSC833 & $47.9 \pm 13.0$ & $10.6 \pm 3.3$ & $0.22 \pm 0.09^{*}$ \\
$m d r 1 a / 1 b(-/-)$ & $39.6 \pm 5.1$ & $21.1 \pm 7.1$ & $0.53 \pm 0.19^{\ddagger}$ \\
$m d r 1 a / 1 b(-/-)+$ PSC833 & $45.4 \pm 11.2$ & $14.7 \pm 2.6$ & $0.32 \pm 0.10^{\S}$ \\
& & & \\
\hline
\end{tabular}

Results are means $\pm \mathrm{SD}(n=4)$ in $\mathrm{ng}\left[{ }^{3} \mathrm{H}\right]$ digoxin equivalent per $\mathrm{ml}$ or gram. Wild-type or mdr1a/1b (-/-) mice received oral PSC833 $(50 \mathrm{mg} /$ $\mathrm{kg}$ ) or vehicle alone $2 \mathrm{~h}$ before intravenous injection of $\left[{ }^{3} \mathrm{H}\right]$ digoxin $(0.05 \mathrm{mg} / \mathrm{kg})$. Statistical significance of difference from vehicle-treated wild-type mice: ${ }^{*} P<0.02 ;{ }^{\ddagger} P<0.005 ;{ }^{\circledR} P<0.002$.

data somewhat: PSC833 treatment or the absence of mdr1type P-gps in $m d r 1 a / 1 b(-/-)$ mice resulted in higher plasma concentrations of $\left[{ }^{3} \mathrm{H}\right]$ digoxin, about three-fold after $4 \mathrm{~h}$, and about ten-fold after $24 \mathrm{~h}$ relative to untreated wild-type mice. This result is likely caused by the delayed elimination of $\left[{ }^{3} \mathrm{H}\right]$ digoxin in mice without functioning mdr1-type P-gps. We corrected for this effect by comparing brain/plasma ratios of $\left[{ }^{3} \mathrm{H}\right]$ digoxin rather than absolute concentrations. The second complication is evident from a comparison of the brain/plasma ratios in $m d r l a / 1 b(-/-)$ mice with or without PSC833 pretreatment (Table III): the presence of PSC833 decreased the distribution of $\left[{ }^{3} \mathrm{H}\right]$ digoxin to the brain by about two-fold after $4 \mathrm{~h}(P<0.001)$.

Nevertheless, it is clear from Table III that PSC833 treatment increased the relative distribution of $\left[{ }^{3} \mathrm{H}\right]$ digoxin from plasma to brain about eight-fold in wild-type mice, from 0.06 to 0.47 ( $4 \mathrm{~h}$ after $\left[{ }^{3} \mathrm{H}\right]$ digoxin injection). The absolute brain concentration of $\left[{ }^{3} \mathrm{H}\right]$ digoxin was increased 19 -fold. The resulting brain to plasma ratio (0.47) was $63 \%$ of that found in PSC833-treated $m d r 1 a / 1 b(-/-)$ mice $(0.75)$, whereas the plasma levels in these groups were comparable (28.4 $\pm 8.1 \mathrm{vs.}$ $35.3 \pm 4.6 \mathrm{ng} / \mathrm{ml}$; see Table III). These data indicate that orally administered PSC833 can extensively, albeit not completely, inhibit P-gp-mediated $\left[{ }^{3} \mathrm{H}\right]$ digoxin transport in the bloodbrain barrier. Similar phenomena with respect to brain/plasma distribution behavior were observed in the bile cannulation ex-

Table II. Influence of PSC833 on Bile Flow and on Bile Acid and Phospholipid Excretion Into Bile in Wild-type Mice

\begin{tabular}{lcc}
\hline & Vehicle & PSC833 \\
\hline Bile acids (nmol/min/100 g) & $415 \pm 126$ & $517 \pm 132$ \\
Phospholipids (nmol/min/100 g) & $68 \pm 13$ & $73 \pm 31$ \\
Bile acid/phospholipid ratio & $6.1 \pm 1.1$ & $7.7 \pm 2.6$ \\
Bile flow $(\mu \mathrm{l} / \mathrm{min} / 100 \mathrm{~g})$ & $7.0 \pm 0.9$ & $6.1 \pm 1.0$
\end{tabular}

PSC 833 was administered orally at $50 \mathrm{mg} / \mathrm{kg} 2 \mathrm{~h}$ before cannulation of the gallbladder. As a control, mice received vehicle (cremophor EL) alone at the same time schedule. Values given are means \pm SD $(n=8)$, and expressed as units per min per $100 \mathrm{~g}$ of liver tissue.
Table III. Plasma and Brain Levels of Radioactivity 4 and $24 \mathrm{~h}$ After intravenous Administration of [3H]digoxin to Mice Pretreated with PSC833 or Vehicle Alone

\begin{tabular}{lccc}
\hline & Plasma & Brain & Ratio brain/plasma \\
\hline & $n g / m l$ & $n g / g$ & \\
& & & \\
4 h after injection & & & \\
Wild-type & $11.7 \pm 5.0$ & $0.7 \pm 0.4$ & $0.060 \pm 0.043$ \\
Wild-type + PSC833 & $28.4 \pm 8.1$ & $13.3 \pm 5.9$ & $0.47 \pm 0.25^{*}$ \\
mdr1a/1b(-/-) & $28.6 \pm 1.4$ & $47.8 \pm 7.8$ & $1.67 \pm 0.28^{\ddagger}$ \\
mdr1a/1b(-/-) + PSC833 & $35.3 \pm 4.6$ & $26.4 \pm 1.4$ & $0.75 \pm 0.11^{\ddagger}$ \\
24 h after injection & & & \\
Wild-type & $0.3 \pm 0.1$ & $0.6 \pm 0.3$ & $2.0 \pm 1.2$ \\
Wild-type + PSC833 & $3.4 \pm 2.9$ & $9.5 \pm 1.1$ & $2.8 \pm 2.4$ \\
mdr1a/1b (-/-) & $5.1 \pm 3.7$ & $101.5 \pm 48.6$ & $19.9 \pm 17.3$ \\
mdr1a/1b (-/-) + PSC833 & $3.0 \pm 2.3$ & $41.8 \pm 11.2$ & $13.9 \pm 11.3$ \\
& & & \\
& & &
\end{tabular}

Results are means $\pm \mathrm{SD}(n=4)$ in $\mathrm{ng}\left[{ }^{3} \mathrm{H}\right]$ digoxin equivalent per $\mathrm{ml}$ or $\mathrm{g}$. Wild-type or $m d r 1 a / 1 b(-/-)$ mice received oral PSC833 $(50 \mathrm{mg} / \mathrm{kg})$ or vehicle alone $2 \mathrm{~h}$ before intravenous injection of $\left[{ }^{3} \mathrm{H}\right]$ digoxin $(0.05 \mathrm{mg} /$ $\mathrm{kg})$. Statistical significance of difference from vehicle-treated wild-type mice: $* P<0.02 ;{ }^{\ddagger} P<0.001$.

periments, i.e., 90 min after intravenous $\left[{ }^{3} \mathrm{H}\right]$ digoxin administration (Table 1).

The 24-h distribution data (Table III) indicate that, even though the brain concentration of $\left[{ }^{3} \mathrm{H}\right]$ digoxin was about $16-$ fold higher in PSC833-treated compared to vehicle-treated wild-type mice (with an 11-fold higher plasma concentration), this difference resulted in only a 1.4-fold increase in brain/ plasma ratio. At this time point, $\left[{ }^{3} \mathrm{H}\right]$ digoxin brain levels and brain/plasma ratios were substantially higher in $m d r 1 a / 1 b(-/-)$ mice with or without PSC833 treatment, and plasma or brain levels did not differ significantly between vehicle- and PSC833treated mdrla/1b (-/-) mice.

An obvious explanation for the strongly diminished effect of PSC833 on the brain/plasma distribution ratio in wild-type mice $24 \mathrm{~h}$ after $\left[{ }^{3} \mathrm{H}\right]$ digoxin administration could be that the PSC833 plasma concentration had dropped below levels sufficient to effectively inhibit P-gp activity in the blood-brain barrier. Measurement of plasma PSC833 levels yielded concentrations of $6-8 \mu \mathrm{g} / \mathrm{ml}, 3-4 \mu \mathrm{g} / \mathrm{ml}$, and $0.5-0.7 \mu \mathrm{g} / \mathrm{ml}$ at 0,4 , and $24 \mathrm{~h}$, respectively, after $\left[{ }^{3} \mathrm{H}\right]$ digoxin administration (i.e., 2,6 , and $26 \mathrm{~h}$ after PSC833 administration; Fig. 3). Plasma PSC833 concentrations did not differ significantly between wild-type and $m d r 1 a / 1 b(-/-)$ mice at these time points. If the optimal inhibition of blood-brain barrier P-gp requires plasma PSC833 levels of at least $3 \mu \mathrm{g} / \mathrm{ml}$, this could well explain the results obtained in Table III.

Interestingly, $6 \mathrm{~h}$ after PSC833 administration, brain/ plasma ratios for PSC833 itself did not differ significantly between wild-type and mdrla/1b (-/-) mice, but $26 \mathrm{~h}$ after administration PSC833 was nearly completely eliminated from wild-type brain but not from $m d r 1 a / 1 b$ (-/-) brain (Fig. 4). Since the plasma levels at this time point were roughly comparable, this suggests that mouse mdr1-type P-gp can transport PSC833 to some extent, although probably not efficiently. This is in line with the recent finding that in vitro, MDR1-transfected polarized pig kidney cells transport PSC833, but only with a low $\mathrm{V}_{\max }$ (Smith et al., manuscript submitted for publication). 


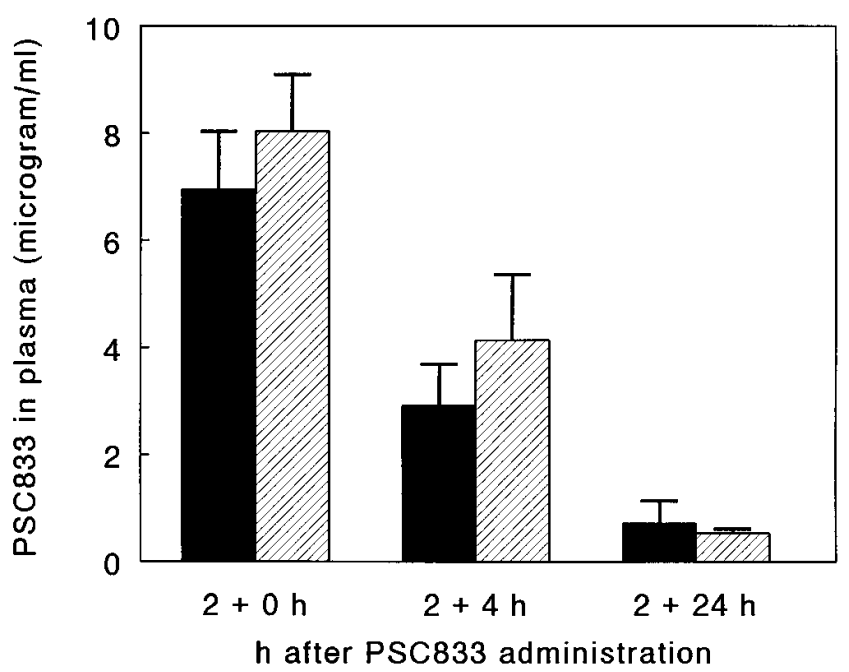

Figure 3. Plasma levels of PSC833 in wild-type and mdrla/1b (-/-) mice. PSC833 plasma levels were determined by immunodetection at 2,6 , and $26 \mathrm{~h}$ after oral PSC 833 administration at $50 \mathrm{mg} / \mathrm{kg}$ (i.e., 0,4 , and $24 \mathrm{~h}$ after intravenous $\left[{ }^{3} \mathrm{H}\right]$ digoxin administration at $0.05 \mathrm{mg} / \mathrm{kg}$ ). Black bars represent levels in wild-type mice, hatched bars represent levels in $m d r 1 a / 1 b(-/-)$ mice. Values depicted are means \pm SD $(n=4)$.

\section{Discussion}

This study documents two potentially important pharmacological effects of an effective reversal agent: it shows that orally administered PSC833 can completely inhibit the intestinal $\mathrm{P}$-gp-mediated excretion of $\left[{ }^{3} \mathrm{H}\right]$ digoxin, and it demonstrates

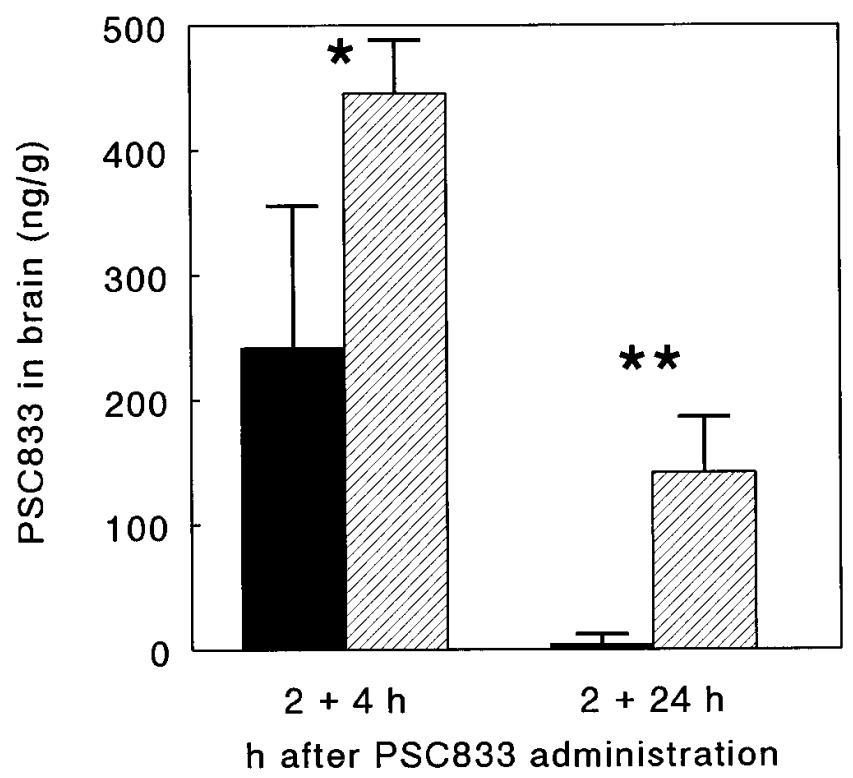

Figure 4. Brain levels of PSC833 in wild-type and $m d r 1 a / 1 b(-/-)$ mice. PSC 833 plasma levels were determined by immunodetection at 2, 6, and $26 \mathrm{~h}$ after oral PSC 833 administration at $50 \mathrm{mg} / \mathrm{kg}$ (i.e., 0,4 , and $24 \mathrm{~h}$ after intravenous $\left[{ }^{3} \mathrm{H}\right]$ digoxin administration at $0.05 \mathrm{mg} / \mathrm{kg}$ ). Black bars represent levels in wild-type mice, hatched bars represent levels in mdr1a/1b (-/-) mice. Levels are expressed in $\mathrm{ng} / \mathrm{g}$ tissue $\pm \mathrm{SD}(n=4) . * P<0.02 ; * * P<0.001$ for each pair of columns. that orally administered PSC833 can extensively inhibit P-gp activity in the blood-brain barrier. In view of the significance of P-gp activity in these prominent pharmacological barriers for many different drugs, these findings may lead to several pharmacological applications as discussed below. Our data further indicate that oral PSC833 treatment can substantially inhibit the hepatobiliary $\left[{ }^{3} \mathrm{H}\right]$ digoxin excretion activity in the liver that is probably partly mediated by mdr1-type P-gps, but also by at least one other hepatic digoxin transporter (and possibly more).

Our previous work with mdrla knockout mice has demonstrated that the intestinal P-gp activity has a profound effect on the efficiency and pattern of excretion of $\left[{ }^{3} \mathrm{H}\right]$ digoxin and paclitaxel $(27,29)$; absence of intestinal (i.e., mdr1a) P-gp substantially delays the elimination of $\left[{ }^{3} \mathrm{H}\right]$ digoxin and paclitaxel from the circulation, and it results in a major shift of $\left[{ }^{3} \mathrm{H}\right]$ digoxin excretion from a predominantly fecal, to a predominantly urinary route. The fecal excretion of paclitaxel dropped from $40 \%$ (intravenous administration) or $87 \%$ (oral administration) in wild-type mice to $<3 \%$ in mdr1a $(-/-)$ mice (29). Moreover, the oral bioavailability of paclitaxel increased more than three-fold, from 11 to $35 \%$, even after correction for the slower elimination of paclitaxel in mdrla $(-/-)$ mice.

As the range of drugs that are substrates for P-gp is nearly endless $(2,35)$, the phenomena observed for digoxin and paclitaxel will probably extend to a large number of other drugs, albeit to varying extents depending on the specific properties of each drug and its handling by the organism. Given the dominant pharmacological role of intestinal P-gp, we expect that the possibility to inhibit its activity completely with an orally administered reversal agent as demonstrated in this study will have several pharmacological applications.

One of the most obvious applications is to increase the oral bioavailability of drugs that are poorly or variably absorbed because of P-gp activity in itself, or because of P-gp activity in combination with intestinal cytochrome P450 activity. This may resolve a major problem in pharmacology (36-39). Indeed, recent experiments have shown that co-administration of oral PSC833 increased the oral area under the plasma-time curve (AUC) for paclitaxel in wild-type mice more than 10fold (40). In addition, Leu and Huang (41) demonstrated that intravenous administration of the P-gp inhibitor quinidine could increase absorption of the P-gp substrate drug etoposide in a rat intestinal perfusion model. Clearly, further experiments are needed to establish the relevance and applicability of this principle in humans, and to determine for what drugs it will apply.

The extensive inhibition of P-gp activity in the blood-brain barrier by oral PSC833 treatment may also have consequences for the pharmacological application of many drugs. In addition to our $\left[{ }^{3} \mathrm{H}\right]$ digoxin results, Drion et al. (42) recently showed that intravenous administration of PSC833 (at $10 \mathrm{mg} / \mathrm{kg}$ ) could increase the brain uptake of the P-gp substrates colchicine and vinblastine about eight- to nine-fold in rats. Although the absence of P-gp negative control animals in this case did not allow an assessment of how effectively blood-brain barrier P-gp was inhibited, the findings indicate that the effects we found for $\left[{ }^{3} \mathrm{H}\right]$ digoxin also apply to other P-gp substrates. We have previously demonstrated that P-gp activity in the blood-brain barrier dramatically affects the toxic and behavioral effects of at least three drugs in the central nervous system (CNS): iver- 
mectin, domperidone, and loperamide $(16,26)$. In addition, we found increased brain accumulation of many other drugs in mdrla $(-/-)$ mice, without extensively pursuing the potential changes in CNS toxicity or pharmacodynamic effects $(16,25$, $26)$. For the drug loperamide we demonstrated a qualitative change in pharmacological effects, as its increased brain accumulation in mdrla (-/-) mice turned it from a peripherally active antidiarrheal drug into an opiate with strong morphinelike activity in the CNS.

Thus, the feasibility of extensively inhibiting blood-brain barrier P-gp activity by administering a reversal agent poses both a potential risk and a window of pharmacological opportunity. The risk is clear: increased CNS toxicity of many different drugs that normally hardly enter the brain owing to P-gp activity. This risk may be further compounded by an increase in plasma levels of the drug, as was already demonstrated in many clinical trials (10). Current clinical trials aimed at treating multidrug resistant cancer using effective P-gp inhibitors should thus be cautiously monitored for inadvertant CNS toxicity of any of the drugs concomitantly administered to the patients. For example, Didier and Loor (43) found that oral coadministration of PSC833 increased the sensitivity of mice to ivermectin more than tenfold, although this study did not measure directly whether the increase in toxicity was mainly due to increased plasma levels, or increased brain/plasma ratios for ivermectin.

The window of opportunity may be less obvious, as its real potential still has to be investigated. A conceptually simple application may be to improve chemotherapy of tumors in the CNS that are effectively protected from cytotoxic agents in the bloodstream by P-gp in the blood-brain barrier. Clearly, in this application one should take great care to avoid drugs that are intrinsically toxic to normal brain cells. Of perhaps more interest, however, is the possibility to open the CNS to the therapeutic potential of drugs that normally do not enter the brain because of efficient back-transport by P-gp, as was the case with loperamide. In view of the amazing number and structural diversity of P-gp substrates (likely also including many derivatized peptide and peptidomimetic drugs), we expect that there will be many more compounds with potential therapeutic properties in the brain that now cannot be applied clinically as they do not enter the CNS because of P-gp (44). Using proper precautions, coadministration of PSC833 or other effective P-gp inhibitors may circumvent this stumbling block, and thus free an entire new range of drugs useful for combatting CNS disorders.

It is as yet unclear by what mechanism PSC 833 affects the brain/plasma distribution of $\left[{ }^{3} \mathrm{H}\right]$ digoxin in $m d r 1 a / 1 b(-/-)$ mice. It may increase the relative affinity of $\left[{ }^{3} \mathrm{H}\right]$ digoxin for components in plasma or blood, or it may decrease the relative affinity of $\left[{ }^{3} \mathrm{H}\right]$ digoxin for the brain compartment (e.g., by competing for $\left[{ }^{3} \mathrm{H}\right]$ digoxin-binding sites in the brain). It may also affect the efficiency of uptake of $\left[{ }^{3} \mathrm{H}\right]$ digoxin into brain cells, for instance by changing the physical behavior of the membranes, potentially resulting in a decreased capacity to allow permeation of the drug. Since PSC833 treatment also decreased the liver/plasma distribution ratio about two-fold in $m d r 1 a / 1 b(-/-)$ mice (data not shown), the effect does not appear to be specific for the brain.

The inhibition of hepatobiliary $\left[{ }^{3} \mathrm{H}\right]$ digoxin excretion in PSC833-treated $m d r 1 a / 1 b(-/-)$ mice demonstrates that PSC833, in addition to blocking the mdr1-type P-gps, also in- hibits another $\left[{ }^{3} \mathrm{H}\right]$ digoxin transporter (or transporters) in vivo. The identity of this transporter is as yet unknown, nor is it clear whether it will transport other drugs, although we expect that it will. It is unlikely to be the canalicular multispecific organic anion transporter, since this transporter is not effectively inhibited by PSC833 (45). Whatever the nature of this transporter, its inhibition by PSC833 may be useful for some pharmacological purposes (e.g., increasing area under the plasma-time curve for drugs), but it may also complicate pharmacological interventions aimed at specifically inhibiting mdr1-type P-gp activity. Moreover, oral PSC833 could not completely inhibit blood-brain barrier P-gp activity, and it decreased the relative brain/plasma distribution of $\left[{ }^{3} \mathrm{H}\right]$ digoxin in $m d r l a / 1 b(-/-)$ mice. Depending on the specific pharmacological aims one has for the use of a reversal agent, we think therefore that it will be useful to develop even better P-gp inhibitors with higher effectivity and/or specificity towards the mdr1-type P-gps. The $m d r 1 a / 1 b$ knockout mice will provide a helpful tool in the further characterization of such improved P-gp inhibitors, and in the exploration of their pharmacological application possibilities.

\section{Acknowledgments}

We thank our colleagues for critical reading of the manuscript. We are indebted to Dr. R.P.J. Oude Elferink for analysis of bile composition, and to A.J. Schrauwers for excellent biotechnical assistance.

This work was supported in part by grant NKI 92-41 of the Dutch Cancer Society to P. Borst and A.J.M. Berns. U. Mayer performed the work described in this study as a fellow of the European Cancer Centre, Amsterdam, The Netherlands.

\section{References}

1. Endicott, J.A., and V. Ling. 1989. The biochemistry of P-glycoproteinmediated multidrug resistance. Annu. Rev. Biochem. 58:137-171.

2. Gottesman, M.M., and I. Pastan. 1993. Biochemistry of multidrug resistance mediated by the multidrug transporter. Annu. Rev. Biochem. 62:385-427.

3. Gros, P., J. Croop, and D. Housman. 1986. Mammalian multidrug resistance gene: complete cDNA sequence indicates strong homology to bacterial transport proteins. Cell. 47:371-380.

4. Chen, C.J., J.E. Chin, K. Ueda, D.P. Clark, I. Pastan, M.M. Gottesman, and I.B. Roninson. 1986. Internal duplication and homology with bacterial transport proteins in the mdr1 (P-glycoprotein) gene from multidrug-resistant human cells. Cell. 47:381-389.

5. Borst, P., and A.H. Schinkel. 1996. What have we learnt thus far from mice with disrupted P-glycoprotein genes? Eur. J. Cancer. 32A:985-990.

6. Tsuruo, T., H. Iida, S. Tsukagoshi, and Y. Sakurai. 1981. Overcoming of vincristine resistance in P388 leukemia in vivo and in vitro through enhanced cytotoxicity of vincristine and vinblastine by verapamil. Cancer Res. 41:19671972.

7. Ford, J.M. 1995. Modulators of multidrug resistance. Hematol. Oncol. Clin. N. Am. 9:337-361.

8. Dalton, W.S., T.M. Grogan, P.S. Meltzer, R.J. Scheper, B.G.M. Durie, C.W. Taylor, T.P. Miller, and S.E. Salmon. 1989. Drug-resistance in multiple myeloma and non-Hodgkin's lymphoma: detection of P-glycoprotein and potential circumvention by addition of verapamil to chemotherapy. J. Clin. Oncol. $7: 415-424$.

9. Sikic, B.I. Modulation of drug resistance: at the threshold. 1993. J. Clin. Oncol. 11:1629-1635.

10. Fisher, G.A., and B.I. Sikic. 1995. Clinical studies with modulators of multidrug resistance. Hematol. Oncol. Clin. No. Am. 9:363-382.

11. Twentyman, P.R., and N.M. Bleehen. 1991. Resistance modification by PSC-833, a novel non-immunosuppressive cyclosporin. Eur. J. Cancer. 27:16391642.

12. Watanabe, T., M. Naito, T. Oh-Hara, J. Itoh, D. Cohen, and T. Tsuruo. 1996. Modulation of multidrug resistance by SDZ PSC 833 in leukemic and solid tumor-bearing mouse models. Jpn. J. Cancer Res. 87:184-193.

13. Hyafil, F., C. Vergely, P. Du Vignaud, and T. Grand-Perret. 1993. In vitro and in vivo reversal of multidrug resistance by GF120918, an acridonecarboxamide derivative. Cancer Res. 53:4595-4602.

14. Witherspoon, S.M., D.L. Emerson, B.M. Kerr, T.L. Lloyd, W.S. Dalton, 
and P.S. Wissel. 1996. Flow cytometric assay of modulation of P-glycoprotein function in whole blood by the multidrug resistance inhibitor GG918. Clin. Cancer Res. 2:7-12.

15. Dantzig, A.H., R.L. Shepard, J. Cao, K.L. Law, W.J. Ehlhardt, T.M. Baughman, T.F. Bumol, and J.J. Starling. 1996. Reversal of P-glycoproteinmediated resistance by a potent cyclopropyldibenzosuberane modulator, LY335979. Cancer Res. 56:4171-4179.

16. Schinkel, A.H., J.J.M. Smit, O. van Tellingen, J.H. Beijnen, E. Wagenaar, L. Van Deemter, C.A.A.M. Mol, M.A. van der Valk, E.C. RobanusMaandag, H.P.J. te Riele, A.J.M. Berns, and P. Borst. 1994. Disruption of the mouse mdr1a P-glycoprotein gene leads to a deficiency in the blood-brain barrier and to increased sensitivity to drugs. Cell. 77:491-502.

17. Schinkel, A.H., U. Mayer, E. Wagenaar, C.A.A.M. Mol, L. van Deemter, J.J.M. Smit, M.A. van der Valk, A.C. Voordouw, H. Spits, O. van Tellingen, et al. 1997. Normal viability and altered pharmacokinetics in mice lacking mdr1-type (drug-transporting) P-glycoproteins. Proc. Natl. Acad. Sci. USA. 94:4028-4033.

18. Croop, J.M., M. Raymond, D. Haber, A. Devault, R.J. Arceci, and P. Gros. 1989. The three mouse multidrug resistance (mdr) genes are expressed in a tissue specific manner in normal mouse tissue. Mol. Cell. Biol. 9:1346-1350.

19. Arceci, R.J., J.M. Croop, S.B. Horwitz, and D. Housman. 1988. The gene encoding multidrug resistance is induced and expressed at high levels during pregnancy in the secretory epithelium of the uterus. Proc. Natl. Acad. Sci. USA. 85:4350-4354.

20. Bommhardt, U., J.-C. Cerotinni, and H.R. MacDonald. 1994. Heterogeneity in P-glycoprotein (multidrug resistance) activity among murine peripheral T cells: correlation with surface phenotype and effector function. Eur. J. Immunol. 24:2974-2981.

21. Thiebaut, F., T. Tsuruo, H. Hamada, M.M. Gottesman, I. Pastan, and M.C. Willingham. 1987. Cellular localization of the multidrug resistance gene product in normal human tissues. Proc. Natl. Acad. Sci. USA. 84:7735-7738.

22. Cordon-Cardo, C., J.P. O'Brien, D. Casals, L. Rittman-Grauer, J.L. Biedler, M.R. Melamed, and J.R. Bertino. 1989. Multidrug resistance gene (P-glycoprotein) is expressed by endothelial cells at the blood-brain barrier sites. Proc. Natl. Acad. Sci. USA. 86:695-698.

23. Chaudhary, P.M., and I.B. Roninson. 1991. Expression and activity of P-glycoprotein, a multidrug efflux pump, in human hematopoietic stem cells. Cell. 66:85-95.

24. Klimecki, W.T., B.W. Futscher, T.M. Grogan, and W.S. Dalton. 1994. P-glycoprotein expression and function in circulating blood cells from normal volunteers. Blood. 83:2451-2458.

25. Schinkel, A.H., E. Wagenaar, L. van Deemter, C.A.A.M. Mol, and P. Borst. 1995. Absence of the mdr1a P-glycoprotein in mice affects tissue distribution and pharmacokinetics of dexamethasone, digoxin, and cyclosporin A. $J$. Clin. Invest. 96:1698-1705.

26. Schinkel, A.H., E. Wagenaar, C.A.A.M. Mol, and L. van Deemter. 1996. P-glycoprotein in the blood-brain barrier of mice influences the brain penetration and pharmacological activity of many drugs. J. Clin. Invest. 97: 2517-2524.

27. Mayer, U., E. Wagenaar, J.H. Beijnen, J.W. Smit, D.K.F. Meijer, J. Van Asperen, P. Borst, and A.H. Schinkel. 1996. Substantial excretion of digoxin via the intestinal mucosa and prevention of long-term digoxin accumulation in the brain by the mdr1a P-glycoprotein. Br. J. Pharmacol. 119:1038-1044.
28. Van Asperen, J., A.H. Schinkel, J.H. Beijnen, W.J. Nooijen, P. Borst, and O. van Tellingen. 1996. Altered pharmacokinetics of vinblastine in mdr1a P-glycoprotein deficient mice. J. Natl. Cancer Inst. 88:994-999.

29. Sparreboom, A., J. Van Asperen, U. Mayer, A.H. Schinkel, J.W. Smit, D.K.F. Meijer, P. Borst, W.J. Nooijen, J.H. Beijnen, and O. van Tellingen. 1997. Limited oral bio-availability and active epithelial excretion of paclitaxel (taxol) caused by P-glycoprotein in the intestine. Proc. Natl. Acad. Sci. USA. 94:20312035.

30. Hoffmann, G., and L. Lendle. 1953. Nachweis extrakardialer Digitaliswirkungen an der Ratte. Arch. Exp. Pathol. Pharmakol. 217:184-193.

31. Cirella, V.N., C.B. Pantuck, Y.J. Lee, and E.J. Pantuck. 1987. Effects of cyclosporine on anesthetic action. Anesth. Analg. 66:703-706.

32. Turley, S.D., and J.M. Dietschy. 1978. Reevaluation of the 3-hydroxysteroid dehydrogenase assay for total bile acids in bile. J. Lipid Res. 19:945-955.

33. Gurantz, D., M.F. Laker, and A.F. Hofmann. 1981. Enzymatic measurement of choline containing phospholipids in bile. J. Lipid Res. 22:373-376.

34. Chanussot, F., D. Botta-Fridlund, P. Lechene de la Porte, V. Sbarra, H. Portugal, A.M. Pauli, J. Hauton, A. Gauthier, and H. Lafont. 1992. Effects of cyclosporine and corticosteroids on bile secretion in the rat. Transplantation (Baltimore). 54:226-231.

35. Ford, J.M., and W.N. Hait. 1990. Pharmacology of drugs that alter multidrug resistance in cancer. Pharmacol. Rev. 42:155-199.

36. Aungst, B.J. 1993. Novel formulation strategies for improving oral bioavailability of drugs with poor membrane permeation or presystemic metabolism. J. Pharm. Sci. 82:979-987.

37. Kolars, J.C., K.S. Lown, P. Schmiedl-Ren, M. Ghosh, C. Fang, S.A. Wrighton, R.M. Merion, and P.B. Watkins. 1994. CYP3A gene expression in human gut epithelium. Pharmacogenetics. 4:247-259.

38. Wacher, V.J., C.-Y. Wu, and L.Z. Benet. 1995. Overlapping substrate specificities and tissue distribution of cytochrome P450 3A and P-glycoprotein: implications for drug delivery and activity in cancer chemotherapy. Mol. Carcinog. 13:129-134.

39. Wacher, V.J., L. Salphati, and L.Z. Benet. 1996. Active secretion and enterocytic drug metabolism barriers to drug absorption. Adv. Drug Deliv. Rev. 20:99-112.

40. Van Asperen, J., O. van Tellingen, A. Sparreboom, A.H. Schinkel, P. Borst, W.J. Nooijen, and J.H. Beijnen. 1997. Enhanced oral bioavailability of paclitaxel in mice treated with the P-glycoprotein blocker SDZ PSC 833. Br. J. Cancer. In press.

41. Leu, B.L., and J.D. Huang. 1995. Inhibition of intestinal P-glycoprotein and effects on etoposide absorption. Cancer Chemother. Pharmacol. 35:432436.

42. Drion, N., M. Lemaire, J.-M. Lefauconnier, and J.-M. Scherrmann. 1996. Role of P-glycoprotein in the blood-brain transport of colchicine and vinblastine. J. Neurochem. 67:1688-1693.

43. Didier, A.D., and F. Loor. 1995. Decreased biotolerability for ivermectin and cyclosporin A in mice exposed to potent P-glycoprotein inhibitors. Int. J. Cancer. 63:263-267.

44. Begley, D.J. 1996. The blood-brain barrier: principles for targeting peptides and drugs to the central nervous system. J. Pharm. Pharmacol. 48:136-146.

45. Böhme, M., G. Jedlitschky, I. Leier, M. Büchler, and D. Keppler. 1994 ATP-dependent export pumps and their inhibition by cyclosporins. Adv. Enzyme Regul. 34:371-380. 